\title{
Monitoring strategies of stream phosphorus under contrasting climate-driven flow regimes
}

\author{
G. Goyenola $^{1}$, M. Meerhoff ${ }^{1,2}$, F. Teixeira-de Mello ${ }^{1}$, I. González-Bergonzoni ${ }^{1,2,3}$, D. Graeber ${ }^{2}$, C. Fosalba ${ }^{1}$,

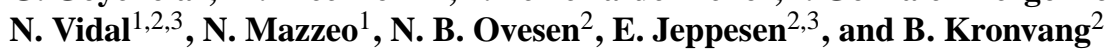 \\ ${ }^{1}$ Departamento de Ecología Teórica y Aplicada, CURE-Facultad de Ciencias, Universidad de la República, \\ Maldonado, Uruguay \\ ${ }^{2}$ Department of Bioscience and Arctic Research Centre, Aarhus University, Silkeborg, Denmark \\ ${ }^{3}$ Sino-Danish Centre for Education and Research, Beijing, China \\ Correspondence to: G. Goyenola (goyenola@gmail.com)
}

Received: 25 February 2015 - Published in Hydrol. Earth Syst. Sci. Discuss.: 26 March 2015

Revised: 16 September 2015 - Accepted: 22 September 2015 - Published: 8 October 2015

\begin{abstract}
Climate and hydrology are relevant control factors determining the timing and amount of nutrient losses from land to downstream aquatic systems, in particular of phosphorus (P) from agricultural lands. The main objective of the study was to evaluate the differences in P export patterns and the performance of alternative monitoring strategies in streams under contrasting climate-driven flow regimes. We compared a set of paired streams draining lowland microcatchments under temperate climate and stable discharge conditions (Denmark) and under sub-tropical climate and flashy conditions (Uruguay). We applied two alternative nutrient sampling programs (high-frequency composite sampling and low-frequency instantaneous-grab sampling) and estimated the contribution derived from point and diffuse sources fitting a source apportionment model. We expected to detect a pattern of higher total and particulate phosphorus export from diffuse sources in streams in Uruguay streams, mostly as a consequence of higher variability in flow regime (higher flashiness). Contrarily, we found a higher contribution of dissolved P in flashy streams. We did not find a notably poorer performance of the low-frequency sampling program to estimate $\mathrm{P}$ exports in flashy streams compared to the less variable streams. We also found signs of interaction between climate/hydrology and land use intensity, in particular in the presence of point sources of $\mathrm{P}$, leading to a bias towards underestimation of $\mathrm{P}$ in hydrologically stable streams and overestimation of $\mathrm{P}$ in flashy streams. Based on our findings, we suggest that the evaluation and use of more accurate monitoring methods, such as automatized flow-proportional
\end{abstract}

water samplers and automatized bankside analyzers, should be prioritized whenever logistically possible. However, it seems particularly relevant in currently flashy systems and also in systems where climate change predictions suggest an increase in stream flashiness.

\section{Introduction}

The global demand for phosphorus for fertilizers is projected to increase in the coming decades, although the existing global reserves will likely be exhausted within this century (Cordell et al., 2009). Nowadays, the global flow of phosphorus runs from mines through farms to aquatic systems, contributing to eutrophication and triggering aquatic ecosystem degradation (Carpenter et al., 1998; Elser and Bennett, 2011). Thus, humanity faces the challenge of sustaining food production while reducing the associated environmental costs.

The biogeochemical processes inside a catchment, which determine the loss of phosphorus from the land to aquatic systems, are mainly dependent on climatic and hydrological regimes (Bormann and Likens, 1967). Streams located in areas with short-duration-high-magnitude rainfall events may respond with frequent and rapid changes in discharge (to be "flashy" streams sensu Baker et al., 2004) and may potentially have a higher risk of diffuse transfer of nutrients from land to water (Cassidy and Jordan, 2011; Haygarth et al., 1999). The importance of understanding hydrology-driven variations in nutrient discharge increases in the current cli- 
mate change scenario where strong hydrological changes are expected in many different parts of the world.

Irrespective of the hydrological nature of the catchments, nutrient monitoring programs are frequently based on lowfrequency sampling at discrete intervals. This kind of sampling strategy complemented by interpolation methods is prone to very high uncertainties due to typical underrepresentation of high-discharge, short-duration events (Defew et al., 2013; Jones et al., 2012; Jordan and Cassidy, 2011; Stelzer and Likens, 2006). A priori, the risk of missing the key moments when phosphorus is delivered to the streams is higher in flashy streams than in hydrologically stable ones. An approach to advance the understanding of how different monitoring schemes capture catchment phosphorus processes in contrasting climate-driven flow regimes is to compare monitoring performances in catchments under different climatic conditions and under different conditions of nutrient inputs.

The main objectives of our study were to evaluate the differences in stream phosphorus (P) export patterns and the performance of alternative monitoring strategies in contrasting climate-driven flow regimes. We expected to detect higher total and particulate $\mathrm{P}$ exports in streams located in sites with higher frequency of extreme rainfall events and higher stream hydrological variability (flashiness). We also expected poorer performance of low-frequency sampling programs under such conditions.

\section{Material and methods}

\subsection{Design rationale: selection of case studies}

We conducted a comparative study of concentrations and export of different $\mathrm{P}$ forms in two paired streams under two distinct climatic-hydrological conditions: temperate climate and stable discharge conditions (Denmark) and subtropical climate and flashy conditions (Uruguay). In both countries, the topography of the selected areas can be described as gently rolling plains (mean slope $<5 \%$ ). Two main causes explaining the differences in flashiness between Denmark and Uruguay are precipitation patterns (annual average precipitation $745 \mathrm{~mm}$ since 1990 in Denmark and $1300 \mathrm{~mm}$ in Uruguay, according to the Danish Meteorological Institute (DMI, 2015) and the National Institute for Agriculture Research, INIA, Uruguay (Castaño et al., 2011)), respectively, and depth of soils and derived water storage capacity. The long-term continuous monitoring data in Danish catchments and the existence of published works evaluating alternative sampling strategies (e.g., Kronvang and Bruhn, 1996) persuaded us to use the temperate streams as the reference systems in our comparison.

In each area, two lowland non-experimental microcatchments $\left(<20 \mathrm{~km}^{2}\right)$ were selected as typical productive systems to represent extremes of land use intensity (hereafter LUI) in each area.

As higher LUI catchments, we selected catchments where intensive farming comprising more than $90 \%$ of the total land area, with arable cropping systems, intensive use of fertilizers, and high density of livestock (Table 1). In the Uruguayan high-LUI catchment, the farming production system was based on forage crops, no-till practices associated with intensive application of mineral fertilizers over the soil surface (Derpsch et al., 2010), dairy cattle feeding all year round in open fields, and no effluent treatment facilities on milking plants. In Denmark, the high-LUI catchment included a rotation cropping system with winter cereals and confined pig farms with slurry storage facilities. In Denmark, most loamy agricultural fields are drained with subsurface tile drainage systems (Grant et al., 1996), and the manure originating from farming activities is reutilized with a demand on a $75 \%$ reuse of $\mathrm{N}$ in slurry.

The lower-LUI catchments were chosen so as to represent local more preserved conditions. The Uruguayan low-LUI catchment was dominated by the natural grasslands of the Pampa biome (Allaby, 2006) and sustained low-density cattle production $(70 \%$ of total area and below 1 head by hectare; Table 1). In contrast, a mixture of deciduous and coniferous forests dominated the Danish low-LUI catchment (Table 1).

The subtropical high-LUI catchment had 170 inhabitants and the low-LUI catchment only 20 inhabitants (National Institute of Statistics, 2011). In the former, the sewage from only 10 households is treated in a facultative pond. All other households in both subtropical catchments had leaking septic tanks. The point sources in the temperate catchments were mainly scattered dwellings without connection to sewage treatment plants. The temperate high-LUI stream received stormwater outlets from a small village whose sewage water is pumped to a treatment plant with tertiary treatment outside the catchment.

Maps including land use for each catchment were included as supplementary material (Fig. S1-4 in the Supplement). Henceforth, we will refer to the temperate Danish streams as "STABLE" and the subtropical Uruguayan streams as "FLASHY", while LUI categorization of the intensive and extensive production catchments will be referred to as "highLUI" and "low-LUI", respectively.

\subsection{Phosphorus monitoring}

Similar gauging stations were established in all four micro-catchments. We applied two alternative nutrient sampling programs: low-frequency instantaneous-grab sampling and high-frequency composite sampling. Instantaneous-grab sampling of water was conducted fortnightly, and P exports were estimated by two daily step interpolation methods. High-frequency composite sampling was undertaken using glacier refrigerated automatic samplers (ISCO-Teledyne). The samplers collected an equal water volume every $4 \mathrm{~h}$, and 
Table 1. Site coordinates (datum WGS84), name and catchment size, dominant soils and land use. Danish catchments are part of Gudenå River basin, and the Uruguayan streams are part of the Santa Lucía Chico River basin.

\begin{tabular}{|c|c|c|c|c|}
\hline Id & $\begin{array}{l}\text { Name } \\
\text { and size }\end{array}$ & Coordinates & $\begin{array}{l}\text { Dominant } \\
\text { soils }\end{array}$ & Land use (area \%) \\
\hline $\begin{array}{l}\text { STABLE } \\
\text { low-LUI }\end{array}$ & $\begin{array}{l}\text { Granslev } \\
740 \text { ha }\end{array}$ & $\begin{array}{l}56^{\circ} 17^{\prime} 2^{\prime \prime} \mathrm{N} \\
9^{\circ} 53^{\prime} 51^{\prime \prime} \mathrm{E}\end{array}$ & $\begin{array}{l}\text { Haplic } \\
\text { Luvisols } 1\end{array}$ & $\begin{array}{l}\text { Forest (59); arable } \\
\text { farming (29); } \\
\text { pasture/meadow (7); } \\
\text { other (5) }\end{array}$ \\
\hline $\begin{array}{l}\text { STABLE } \\
\text { high-LUI }\end{array}$ & $\begin{array}{l}\text { Gelbæk } \\
1180 \text { ha }\end{array}$ & $\begin{array}{l}56^{\circ} 13^{\prime} 29^{\prime \prime} \mathrm{N} \\
9^{\circ} 48^{\prime} 41^{\prime \prime} \mathrm{E}\end{array}$ & $\begin{array}{l}\text { Gleyic } \\
\text { Luvisols } 1\end{array}$ & $\begin{array}{l}\text { Arable farming (92); } \\
\text { forest (2); urban (1); } \\
\text { other (5) }\end{array}$ \\
\hline $\begin{array}{l}\text { FLASHY } \\
\text { low-LUI }\end{array}$ & $\begin{array}{l}\text { Chal-Chal } \\
1880 \text { ha }\end{array}$ & $\begin{array}{l}33^{\circ} 49^{\prime} 31^{\prime \prime} \mathrm{S} \\
56^{\circ} 16^{\prime} 55^{\prime \prime} \mathrm{W}\end{array}$ & $\begin{array}{l}\text { Luvic } \\
\text { Phaeozem } \\
\text { and Eutric } \\
\text { Vertisols }^{2}\end{array}$ & $\begin{array}{l}\text { Extensive pasture } \\
(\sim 70) \text {; arable farming } \\
(\sim 30)\end{array}$ \\
\hline $\begin{array}{l}\text { FLASHY } \\
\text { high-LUI }\end{array}$ & $\begin{array}{l}\text { Pintado } \\
840 \text { ha }\end{array}$ & $\begin{array}{l}33^{\circ} 54^{\prime} 13^{\prime \prime} \mathrm{S} \\
56^{\circ} 00^{\prime} 23^{\prime \prime} \mathrm{W}\end{array}$ & $\begin{array}{l}\text { Eutric } \\
\text { Regosols }^{2}\end{array}$ & $\begin{array}{l}\text { Arable farming and } \\
\text { dairy farms (90); } \\
\text { extensive pasture (7); } \\
\text { urban (3) }\end{array}$ \\
\hline
\end{tabular}

Source: ${ }^{1}$ World Reference Soil Database classification, European Commission and European Soil Bureau Network (2004); ${ }^{2}$ SOTERLAC database, ISRIC Foundation, (http://www.isric.org). STABLE:

low-flashiness Danish streams; FLASHY: Uruguayan flashy streams; low- and high-LUI: low and high land use intensity.

the composite samples were also collected fortnightly. The final phosphorus concentration in the only sampler carboy thus represented a time-proportional average for the fortnightly sampling period. As the high-frequency composite samples integrated more information (i.e., shorter time steps, with higher probability of capturing extreme events), we expected this method to provide better estimates of the "true" exported $P$ from the catchments. Based on this assumption, we evaluated the deviation relative to the estimation methods based on instantaneous-grab samples.

We analyzed the measurements and results from a 2-year monitoring period (March 2010 to March 2012 in STABLE; January 2011 to January 2013 in FLASHY).

\subsection{Meteorological and hydrometric monitoring}

In all catchments, CR10X data loggers (Campbell Scientific Ltd.) collected data every $10 \mathrm{~min}$. In the FLASHY streams, we used CS450 Submersible Pressure Transducers (Campbell Scientific Ltd.) for water stage monitoring as well as HMP45C temperature probes (Campbell Scientific Ltd.) and Rain-O-Matic Professional rainfall automatized gauges (Pronamic). In the STABLE catchments, water level was registered with PDCR 1830 pressure sensors (Druck), while meteorological information was obtained from the Danish Meteorological Institute monitoring network based on a $10 \mathrm{~km} \times 10 \mathrm{~km}$ grid.

Periodic instantaneous flow measurements were taken using a C2-OTT Kleinflügel, transferring data to software for the calculation of instantaneous discharge (VB-Vinge 3.0, Mølgaard Hydrometri). Non-linear stable regressions between stage and discharge at each monitoring station (rating curves) were fitted. The rating curves were used to generate a 10 min discharge data series utilizing the HYMER software (http://www.orbicon.com). For comparisons, discharge data are reported as area-specific runoff.

\subsection{Phosphorus analysis}

All instantaneous-grab and composite water samples were analyzed for total phosphorus (TP), total dissolved phosphorus (TDP), and particulate phosphorus (PP). In addition, soluble reactive phosphorus (SRP) and soluble non-reactive phosphorus (NSRP) were also estimated from instantaneousgrab samples.

Instantaneous-grab samples for TDP and SRP analysis were filtered through $0.45 \mu \mathrm{m}$ membranes. For TDP analysis, STABLE high-frequency composite samples were filtered using $0.45 \mu \mathrm{m}$ pore size membranes, while FLASHY high-frequency composite samples were filtered using Whatman GF/C (pore size $1.2 \mu \mathrm{m}$ ). To detect possible bias derived from the type of filter used, we performed a Kruskal-Wallis test on the proportional contribution of TDP to TP between FLASHY instantaneous-grab and high-frequency composite samples and found no significant differences. Consequently, we consider grab and composite TDP samples to be comparable. Particulate phosphorus (PP) was estimated as the difference between TP and TDP. Soluble non-reactive phos- 
Table 2. Yearly accumulated rainfall and runoff in mm (direct measures), runoff ratio (percentage of rainfall water exported as runoff), and the R-B index (Richards-Baker index) of flashiness for each monitored year. Stormflow contribution: percent contribution of stormflow to total flow was estimated for the complete data set (2 years). STABLE: low-flashiness Danish streams; FLASHY: Uruguayan flashy streams; low- and high-LUI: low and high land use intensity.

\begin{tabular}{lllll}
\hline & $\begin{array}{l}\text { STABLE } \\
\text { low-LUI }\end{array}$ & $\begin{array}{l}\text { STABLE } \\
\text { high-LUI }\end{array}$ & $\begin{array}{l}\text { FLASHY } \\
\text { low-LUI }\end{array}$ & $\begin{array}{l}\text { FLASHY } \\
\text { high-LUI }\end{array}$ \\
\hline Accumulated rainfall 1st year & $770 \mathrm{~mm}$ & $778 \mathrm{~mm}$ & $1030 \mathrm{~mm}$ & $1196 \mathrm{~mm}$ \\
Accumulated rainfall 2nd year & $756 \mathrm{~mm}$ & $766 \mathrm{~mm}$ & $1010 \mathrm{~mm}$ & $1405 \mathrm{~mm}$ \\
Total accumulated runoff 1st year & $515 \mathrm{~mm}$ & $223 \mathrm{~mm}$ & $170 \mathrm{~mm}$ & $235 \mathrm{~mm}$ \\
Total accumulated runoff 2nd year & $472 \mathrm{~mm}$ & $198 \mathrm{~mm}$ & $294 \mathrm{~mm}$ & $255 \mathrm{~mm}$ \\
Runoff ratio 1st year & $66.9 \%$ & $28.6 \%$ & $16.5 \%$ & $19.6 \%$ \\
Runoff ratio 2nd year & $62.4 \%$ & $25.9 \%$ & $29.1 \%$ & $18.2 \%$ \\
R-B index 1st year & 0.1 & 0.3 & 1.0 & 1.3 \\
R-B index 2nd year & 0.1 & 0.3 & 0.9 & 1.2 \\
Stormflow contribution $(\%)$ & $11.8 \%$ & $36.4 \%$ & $60.8 \%$ & $70.6 \%$ \\
\hline
\end{tabular}

phorus (SNRP) was also calculated as the difference between TDP and SRP.

All the samples were determined as molybdate reactive $\mathrm{P}$ by equivalent spectrophotometric methods, preceded by strong oxidation with a solution of potassium persulfate, boric acid, and sodium hydroxide following Valderrama (1981).

\subsection{Data processing and analysis}

Climatic and runoff patterns were explored in order to investigate the main parameters relevant for $\mathrm{P}$ temporal dynamics. As a proxy of catchment water balance, the runoff ratio (i.e., annual percentage of rainfall water exported as runoff) was calculated (Wu et al., 2013). Additionally, to quantify the variation in flow regime we calculated the Richards-Baker index (hereafter R-B index; Baker et al., 2004). The R-B index allows for evaluation of the "flashiness" or the annual ratio of absolute day-to-day fluctuations of streamflow relative to total flow (Baker et al., 2004). Increasing its value with increasing flashiness, the R-B index varies between 0 and infinity and assumes a value of 1 when the accumulated volume of daily oscillations has the same magnitude as the annually accumulated discharge. The relative contribution of baseflow to total streamflow was estimated from daily hydrographs using the automatic routine proposed by Arnold et al. (1995) as an indicator of the deeper groundwater contribution. Percent contribution of stormflow to total flow was estimated as complementary to the baseflow contribution (Table 2).

The statistical relationship between all phosphorus compounds from instantaneous-grab samples was analyzed by Spearman rank order correlation. The temporal dynamics of $\mathrm{P}$ forms were followed for total P (TP), particulate P (PP), total dissolved $\mathrm{P}$ (TDP) and soluble reactive $\mathrm{P}$ (SRP), as minimum (min), median (med) and maximum (max) range and interquartile range (IQR). The statistical comparisons of $P$ temporal dynamics between the four streams were conducted using Kruskal-Wallis tests (Zar, 2010), followed by a post hoc pairwise multiple comparison procedure when appropriate (Dunn, 1964).

Three different methods were used for the calculation of stream P export. The first method was based on multiplying the TP and TDP concentrations obtained from the highfrequency fortnight composite samples by the accumulated discharge for the same time period (Kronvang and Bruhn, 1996). Missing data from the relatively short periods when the automatic samplers were not in operation (e.g., frozen in Denmark) were re-generated through linear interpolation of concentrations (Jones et al., 2012).

Secondly, we calculated exported TP and TDP from the low-frequency instantaneous-grab data by two alternative methods of concentration interpolation: linear (Kronvang and Bruhn, 1996) and concentration-discharge relationships (Bowes et al., 2008). Daily real and interpolated concentrations were subsequently multiplied by daily accumulated discharge to obtain daily export estimates.

Concentration-discharge relationships $(C-Q)$ were established based on instantaneous-grab samples for all four streams by applying the load apportionment model developed by Bowes et al. (2008). This simple modeling approach does not require GIS information on land use, catchment size, population, or livestock density and may act as a valuable and versatile tool for catchment managers to determine suitable catchment mitigation options (Bowes et al., 2008). Several authors have found similar relationships and used them to characterize P dynamics (e.g., Meyer and Likens, 1979), calculate P sources (e.g., Bowes et al., 2008), or to calculate P transport (e.g., Kronvang and Bruhn, 1996).

The Bowes et al. (2008) method assumes that the load of phosphorus from point and diffuse sources can be modeled as a power-law function of the river volumetric flow rate (Eq. 1). The total load of $\mathrm{P}$ at the sampling point is then a linear combination of the loads from diffuse and point source inputs, as shown in Eq. (1): 
$\mathrm{PC}=$ dso_PC + pso_P $=A \cdot Q^{B-1}+C Q^{D-1}$,

where PC is phosphorus concentration, dso_PC is diffuse source originated PC, and pso_PC the point-source originated PC. $Q$ is discharge (daily accumulated), while $A, C$, (proportionality constants) and $B, D$ (exponents) are empirically determined parameters. Parameter estimation was conducted by using a nonlinear generalized reduced gradient method to select values that minimize the residual sum of squares. Parameter $B$ was constrained to values lower than 1 (dilution effect over point contributions) and $D$ values greater than 1 (at no flow, the diffuse inputs tend to be zero and to increase with increasing flow). Each established $C-Q$ relationship was used for the calculation of daily mean concentrations and then multiplied by the daily discharge to achieve daily exports. The proportional annual contribution from point sources and diffuse sources was also calculated with this method.

For FLASHY catchments, we estimated the maximum P contribution from human inhabitants based on the composition of household wastewater (i.e., urine, faeces, and greywater) and biodegradable solid waste per person and year based on Vinnerås (2002). For STABLE catchments, we estimated the total annual load from scattered dwellings not connected to sewage treatment plants and stormwater outlets from validated models (Wiberg-Larsen et al., 2013).

The relative contribution of PP to total exported $\mathrm{P}$ was estimated based on data from low-frequency instantaneousgrab sampling and linear interpolation, high-frequency composite sampling, and flow-weighted concentrations (FWC) estimated from high-frequency composite samples on a monthly basis. FWC estimation allows calculation of a flownormalized comparison of $\mathrm{P}$ concentrations between catchments.

\section{Results}

\subsection{Climate and hydrology}

The climate characteristics of the study period can be considered typical years for both Denmark and Uruguay. During the study period, minimum, mean, median, and maximum air temperatures were between 8 and $12^{\circ} \mathrm{C}$ lower in the temperate/STABLE catchments than in the subtropical/FLASHY catchments (Fig. 1). The annual average temperature in the temperate/STABLE catchments was around $8.8^{\circ} \mathrm{C}$ and ranged between -7.0 and $20.4{ }^{\circ} \mathrm{C}$. The corresponding figures for the subtropical/FLASHY catchments were around $17.5^{\circ} \mathrm{C}$ and ranged between 3.7 and $32.2^{\circ} \mathrm{C}$.

In both climates, catchments showed similar intra-yearly distributed rain patterns, but with marked differences in frequency and intensity (Fig. 2). In the STABLE catchments, it rained almost 6 out of 10 days $(58 \%)$, the rain frequency being nearly half in the FLASHY catchments

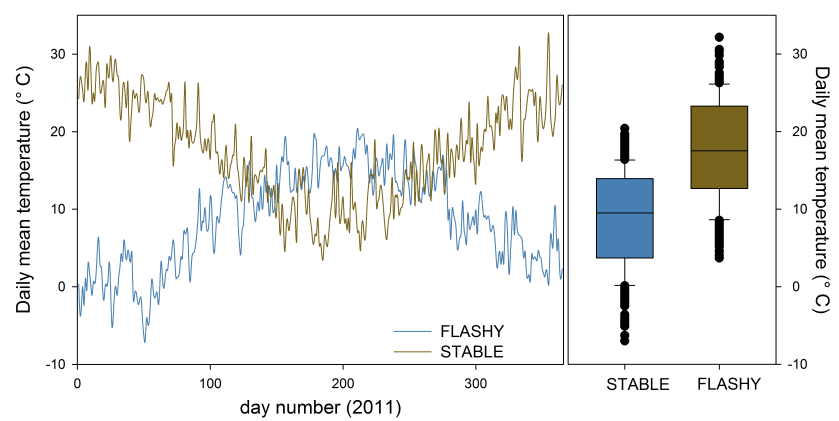

Figure 1. Left panel: mean daily air temperature variation for a temperate/STABLE (Danish) and a subtropical/FLASHY (Uruguayan) catchment in 2011. Right panel: boxplots of the same data. The boundary of the box closest to zero indicates the 25th percentile, a line within the box marks the median, and the boundary of the box farthest from zero indicates the 75th percentile. Whiskers above and below the box indicate the 90th and 10th percentiles. Black dots display outliers.

(31\%). Although there were more rainy days in the STABLE catchments, the daily average amount of rainfall was lower $\left(3.4 \mathrm{~mm} \mathrm{day}^{-1}\right)$ than in FLASHY catchment where it amounted to $10.7 \mathrm{~mm} \mathrm{day}^{-1}$. Only one event of $50 \mathrm{~mm} \mathrm{day}^{-1}$ was registered in the STABLE catchments during the 2year study period, while in the FLASHY catchments rainfall events $>50 \mathrm{~mm} \mathrm{day}^{-1}$ occurred approximately $1.5 \%$ of the days, reaching extremes of $>100 \mathrm{~mm}$ day $^{-1}$. The annual rainfall was 1.44 times higher in the FLASHY than in the STABLE catchments (Table 2).

Most of the water flowing in the FLASHY streams was exported during stormflow conditions (stormflow contribution $>60.8 \%$ ), while in the STABLE streams water was exported during baseflow conditions (stormflow contribution $<36.4 \%$; Table 2). The STABLE/low-LUI stream showed a very different hydrological behavior than the other three streams in that a very high percentage of the rainfall was discharged ( $>62 \%$ ), with high minimum flows and low temporal variability (Fig. 2 and Table 2).

The Danish streams exhibited stable hydrological behavior characterized by low inter-annual variability of total discharge, and also low variability at the daily scale (the R-B index never reached values higher than 0.3; Table 2). In contrast, the Uruguayan streams could be classified as FLASHY systems, with an R-B index ranging around 1 (0.9-1.3; Table 2). The stream draining the high-LUI catchments was the most flashy (Table 2).

\subsection{Phosphorus temporal dynamics}

Total $\mathrm{P}$ concentrations were positively correlated with all other $\mathrm{P}$ fractions (PP, TDP, SRP, SNRP) in STABLE and FLASHY/high-LUI streams, whereas in the low-LUI streams TP only showed a significant relationship with PP in the STABLE and with TDP and PP in the FLASHY stream 
Table 3. Correlation matrices of total (TP), particulate (PP), total dissolved (TDP), soluble reactive (SRP), and soluble non-reactive (SNRP) phosphorus from instantaneous-grab samples. Upper and lower triangles of each matrix refer to high- and low-LUI conditions, respectively. Numeric values represent Spearman rank order correlation and were included only when significant $(p \leq 0.05)$. ns: non-significant. STABLE: low-flashiness Danish streams; FLASHY: Uruguayan flashy streams; low- and high-LUI: low and high land use intensity.

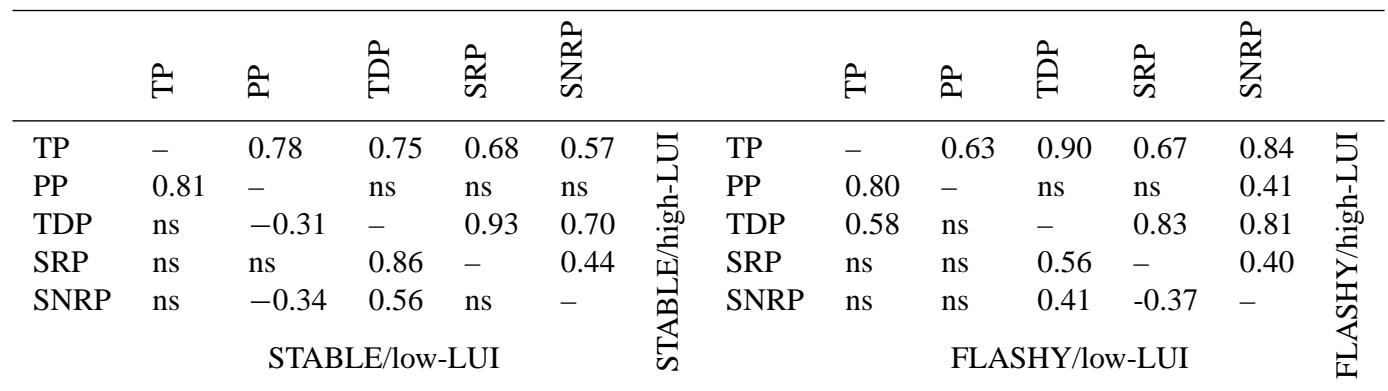
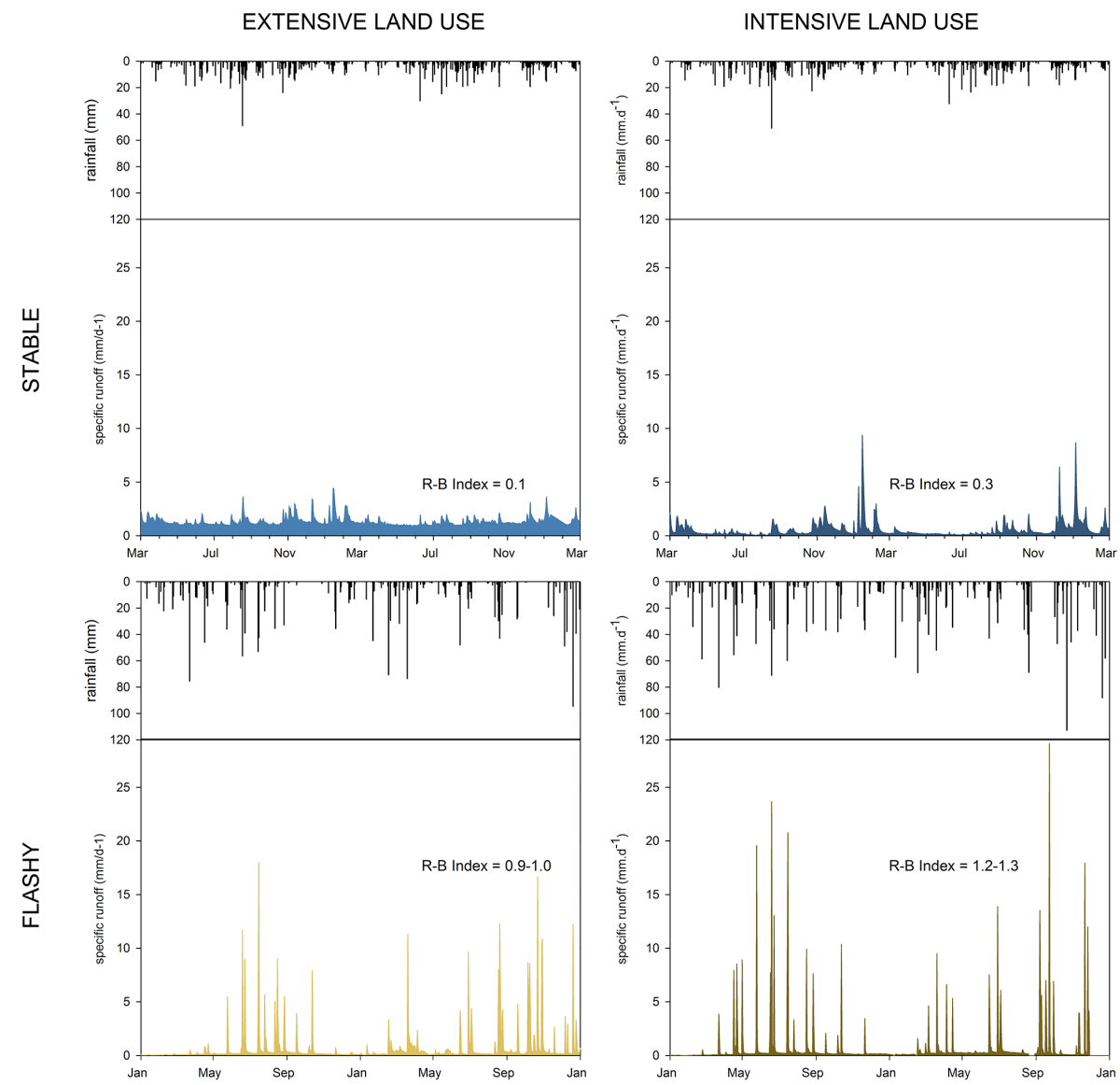

Figure 2. Accumulated daily rainfall and specific runoff hydrographs for the four monitored streams (temperate/STABLE: Danish; subtropical/FLASHY: Uruguayan). For each variable a fixed scale was used to aid visual comparison. R-B index (Richards-Baker index) of flashiness.

(Table 3). The relationships between TDP and SRP were weaker but significant $(p<0.05)$ in the low-LUI streams than in the high-LUI ones under both climatic conditions (Table 3). The contributions of PP to TP were relatively similar in the low- and high-LUI catchments in STABLE, but in FLASHY the proportion of PP decreased with declining intensity of land use (Table 3). The strongest relationships between PP and TP were found in both STABLE streams and the FLASHY/low-LUI stream (Table 3). In contrast, in FLASHY/high-LUI, TDP, and particularly SNRP, showed the strongest relationship with TP (Table 3). Negative relationships were found solely for low-LUI streams, between 
PP and TDP, PP and SNRP for the STABLE stream and between SNRP and SRP for the FLASHY stream (Table 3).

Median TP concentrations calculated for the four streams differed significantly $(H=107.8 ; p \leq 0.001)$, being pronouncedly higher in the FLASHY/high-LUI stream than in any of the others $(\min =271 ; \operatorname{med}=1.024$; $\max =4436 \mu \mathrm{g} \mathrm{PL}^{-1}$; Fig. 3). All other paired comparisons of TP revealed no significant differences, except for the STABLE streams where the TP concentration was significantly lower in the stream draining the high-LUI catchment (median $=76 \mu \mathrm{g} \mathrm{PL}^{-1}$ ) than in the low-LUI catchment (med $=108 \mu \mathrm{g} \mathrm{PL}^{-1}$; Fig. 3). No differences were registered between the STABLE and FLASHY/low-LUI catchments (med $=100 \mu \mathrm{g} \mathrm{PL}^{-1}$; Fig. 3).

A significant difference $(H=43.6 ; p \leq 0.001)$ in median PP concentrations was found between most streams (Fig. 3), with highest and lowest values being registered in the FLASHY high-LUI and low-LUI streams (median $=146$ and $25 \mu \mathrm{g} \mathrm{PL}^{-1}$, respectively) and intermediate values in the STABLE streams (median $=52 \mu \mathrm{g} \mathrm{PL}^{-1}$ in the high-LUI and $80 \mu \mathrm{g} \mathrm{PL}^{-1}$ in the low-LUI stream). Particulate $\mathrm{P}$ concentrations were highest in the STABLE low-LUI stream and vice versa in the FLASHY streams. As expected, the STABLE streams exhibited lower temporal variation in PP than the FLASHY streams $\left(\mathrm{IQR}=23-37\right.$ and $53-227 \mu \mathrm{PL}^{-1}$, respectively).

Furthermore, a significant difference in median TDP concentrations occurred ( $H=133.3 ; p \leq 0.001$; Fig. 3 ). Post hoc analysis revealed statistical equivalence only for the STABLE streams (median $=28$ and $23 \mu \mathrm{g} \mathrm{PL}^{-1}$ for lowand high-LUI streams). Intermediate TDP concentrations were found in FLASHY/low-LUI and the highest concentrations appeared in the FLASHY/ high-LUI stream (median $=74$ and $756 \mu \mathrm{g} \mathrm{PL}^{-1}$, respectively; Fig. 3).

The median SRP concentrations also exhibited statistically significant differences between the streams $(H=141.2$; $p \leq 0.001$; Fig. 3). SRP levels resembled TDP, with the lowest concentrations in the STABLE streams (median: $2 \mu \mathrm{g} \mathrm{PL}^{-1}$ in both), intermediate levels in the FLASHY/lowLUI stream (median: $45 \mu \mathrm{g} \mathrm{PL}^{-1}$ ), and the highest levels in the FLASHY/ high-LUI (median: $659 \mu \mathrm{g} \mathrm{P} \mathrm{L}{ }^{-1}$; Fig. 3). SRP in the STABLE streams never exceeded $23 \mu \mathrm{g} \mathrm{PL}^{-1}$, and in the FLASHY/low-LUI stream it never exceeded $87 \mu \mathrm{g} \mathrm{PL}^{-1}$. In contrast, the FLASHY/high-LUI stream never had SRP concentrations lower than $219 \mu \mathrm{g} \mathrm{PL}^{-1}$ and SRP reached a maximum concentration of $1920 \mu \mathrm{g} \mathrm{PL}^{-1}$ (Fig. 3).

\subsection{Modeling phosphorus inputs from diffuse and point sources}

Graphical exploration of $C-Q$ relationships for the FLASHY streams showed the typical pattern described by Bowes et al. (2008), with high TP concentrations at low discharges followed by steeply declining TP concentrations with increasing discharge (dilution associated with point source-

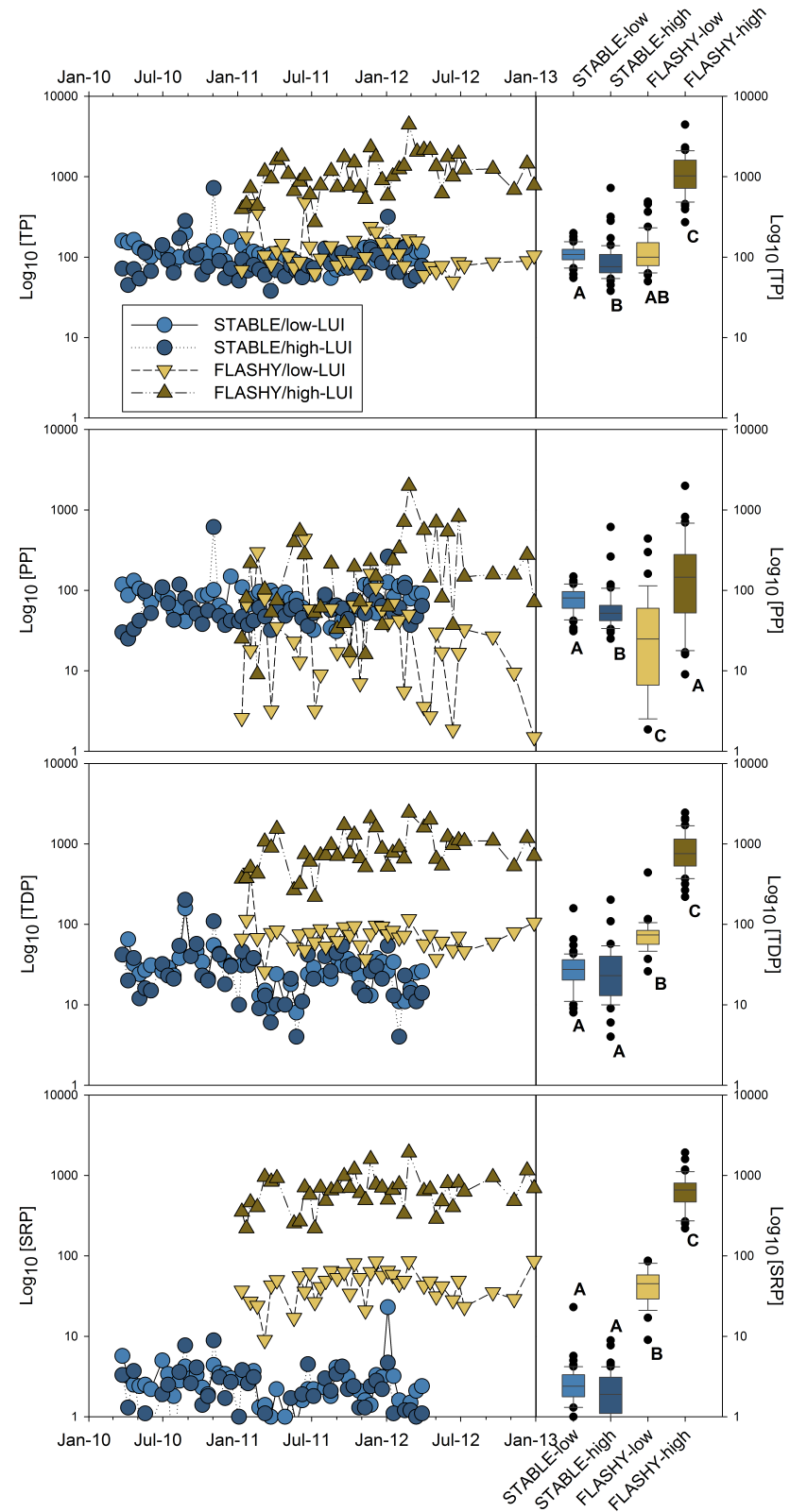

Figure 3. From top to bottom panels: temporal variation of total (TP), particulate (PP), total dissolved (TDP), and soluble reactive phosphorus (SRP) concentrations from grab samples for all the monitored catchments. $\log _{10}$ scale was selected on the vertical axe to improve vizualisation. The phosphorus concentration is always expressed as $\mu \mathrm{gL}^{-1}$. Right panels: boxplots are based on the same data. Letters A, B, and C are used to display statistical groups according post hoc paired comparison analysis. The boundary of the box closest to zero indicates the 25 th percentile, a line within the box marks the median, and the boundary of the box farthest from zero indicates the 75th percentile. Whiskers above and below the box indicate the 90th and 10th percentiles. Black dots display outliers. STABLE: low-flashiness Danish streams; FLASHY: Uruguayan flashy streams; low- and high-LUI: low and high land use intensity. 

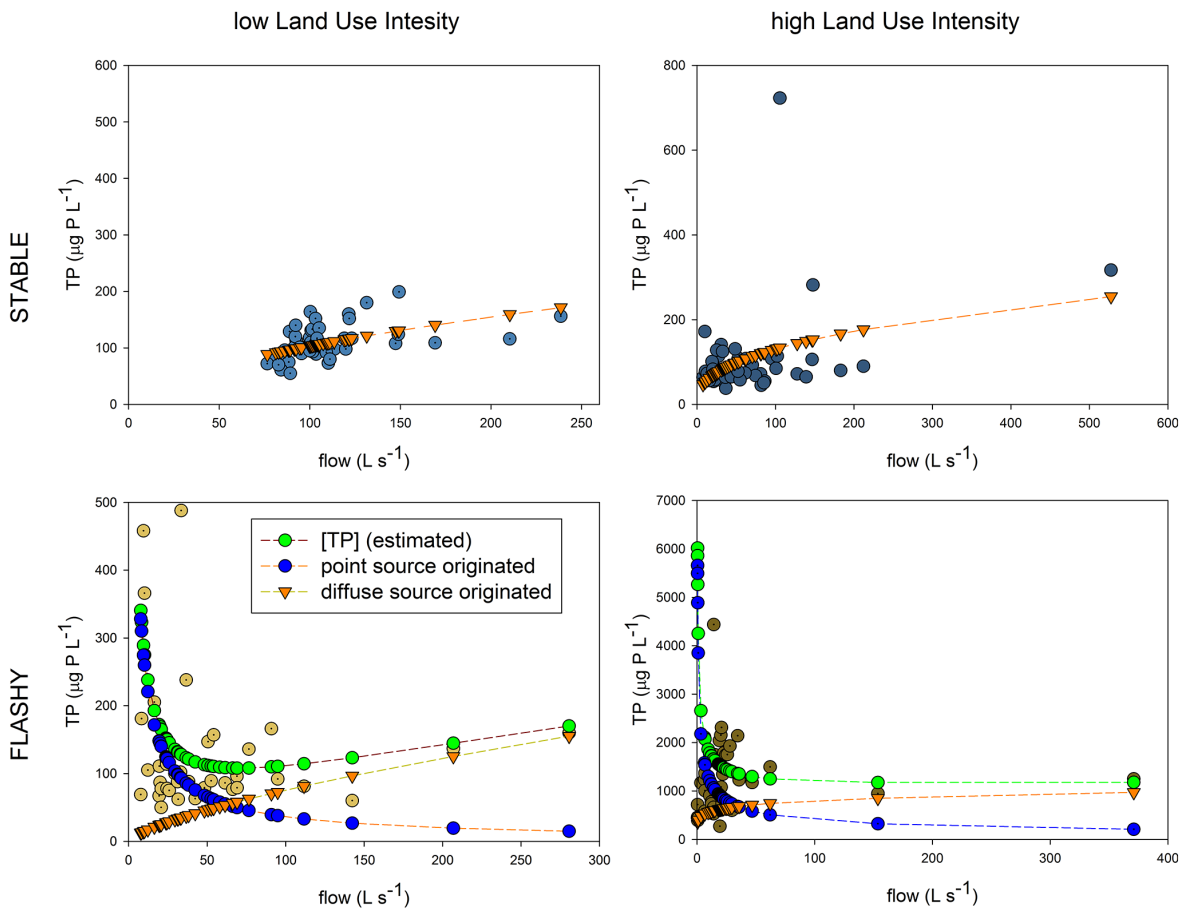

MODELED POINT SOURCE TP CONTRIBUTION

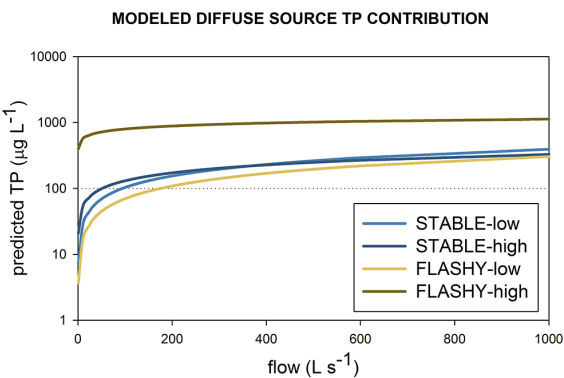

Figure 4. Scatterplots of total phosphorus (TP) concentrations of instantaneous-grab samples relative to discharge from the four streams. The dots connected by lines represent the predicted values according to the load apportionment model (see Table 4). For STABLE catchments, only the diffuse originated term of the model is included. Lowest graphs display the predicted TP concentration of all catchments from point (left panels) and diffuse sources (right panels) for a range of 0 to $1000 \mathrm{~L} \mathrm{~s}^{-1}$. Note the $\log _{10}$ scale for TP. STABLE: low-flashiness Danish streams; FLASHY: Uruguayan flashy streams; low- and high-LUI: low and high land use intensity.

originated $\mathrm{P}$ input), and a less pronounced increase in concentrations at higher discharges (associated with diffuse source-originated $\mathrm{P}$ inputs; Fig. 4). The $C-Q$ relationships for the two STABLE streams did not show any dilution effect associated with point source inputs; therefore, the best fitting was obtained when considering only a diffuse input signal (Fig. 4; Table 4). The performance of the models evaluated with the Nash-Sutcliffe model efficiency coefficient was generally low (Moriasi et al., 2007), reaching a maximum value of 0.25 for the STABLE/low-LUI stream (Table 4).

When considering the relationships established for point source-originated TP for the FLASHY streams, we found a higher exponent $(B)$ in the $C-Q$ relationships for the highLUI catchment (Table 4). As a consequence, the decrease in $\mathrm{TP}$ with increasing flow (the dilution effect) was less pro-
Table 4. Estimated parameters for the load apportionment model fitted for each stream. RSS: residual sum of squares. NSC: NashSutcliffe model efficiency coefficient. STABLE: low-flashiness Danish streams; FLASHY: Uruguayan flashy streams; low- and high-LUI: low and high land use intensity.

\begin{tabular}{llllll}
\hline Source & Parameter & $\begin{array}{l}\text { STABLE } \\
\text { low-LUI }\end{array}$ & $\begin{array}{l}\text { STABLE } \\
\text { high-LUI }\end{array}$ & $\begin{array}{l}\text { FLASHY } \\
\text { low-LUI }\end{array}$ & $\begin{array}{l}\text { FLASHY } \\
\text { high-LUI }\end{array}$ \\
\hline \multirow{2}{*}{ Point } & $A$ & 0 & 0 & 1915 & 2550 \\
& $B$ & - & - & 0.140 & 0.501 \\
\hline \multirow{2}{*}{ Diffuse } & $C$ & 7.145 & 20.677 & 3.658 & 399.000 \\
& $D$ & 1.58 & 1.40 & 1.64 & 1.15 \\
\hline \multirow{2}{*}{ Global } & RSS $\left(10^{3}\right)$ & 42.5 & 460 & 253 & 36362 \\
& NSC & 0.25 & 0.12 & 0.12 & 0.10 \\
\hline
\end{tabular}




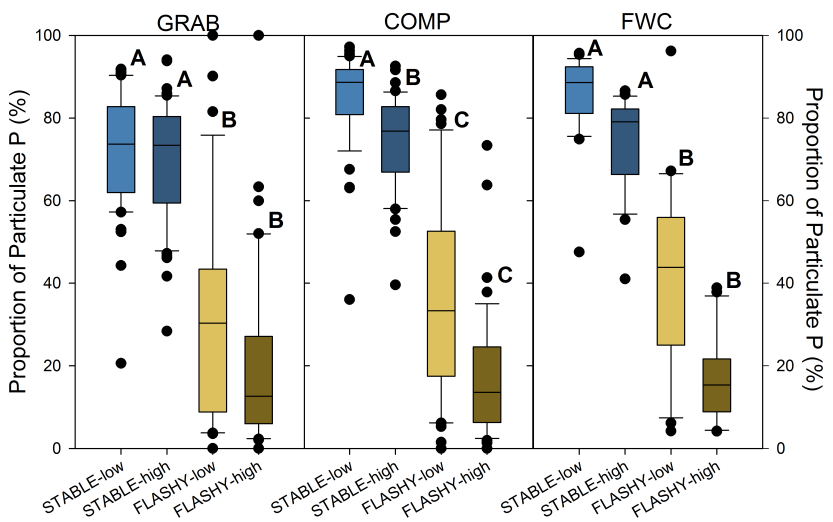

Figure 5. Contribution of particulate phosphorus (PP) to exported total phosphorus (TP). Left boxplots are based on instantaneousgrab sampling and linear interpolation estimation, centre boxplots are based on composite data, and the right boxplot on flow-weighted concentrations. Letters A, B, and C are used to display statistical groups according post hoc paired comparison analysis. The boundary of the box closest to zero indicates the 25 th percentile, a line within the box marks the median, and the boundary of the box farthest from zero indicates the 75th percentile. Whiskers above and below the box indicate the 90th and 10th percentiles. STABLE: lowflashiness Danish streams; FLASHY: Uruguayan flashy streams; low- and high-LUI: low and high land use intensity.

nounced for the high- than the low-LUI stream (at $1000 \mathrm{~L} \mathrm{~s}^{-1}$ the FLASHY/high-LUI catchment reached $85 \mu \mathrm{gL}^{-1}$, while the FLASHY/low-LUI dropped to $5 \mu \mathrm{g} \mathrm{PL}^{-1}$; Fig. 4).

Considering only diffuse sources of TP, we found a higher coefficient $(C)$ but slightly lower exponents $(D)$ in the $C-Q$ relationships established for the high-LUI than for the lowLUI catchments under both climate conditions (Fig. 4 and Table 4). However, the FLASHY/high-LUI stream always had higher TP concentrations from diffuse sources than the other streams (Fig. 4).

\subsection{Estimation of phosphorus export}

Comparing TP export estimates based on the high-frequency composite sampling, we found an underestimation pattern when applying the low-frequency sampling/linear interpolation method for both STABLE catchments and an overestimation for the FLASHY catchments (Table 6). This bias was always higher for the low- than for the high-LUI catchments (Table 6).

The TP and TDP export from the FLASHY/high-LUI catchment was higher than in the other three catchments (Table 5). Moreover, for STABLE streams, the TP export was always higher from the low-LUI than from the high-LUI catchment (Table 5).

Also comparing with the high-frequency composite estimates, the $C-Q$ relationships used to calculate exported TP produced more accurate results than the linear interpolation for the two high-LUI catchments, irrespective of climatic re-

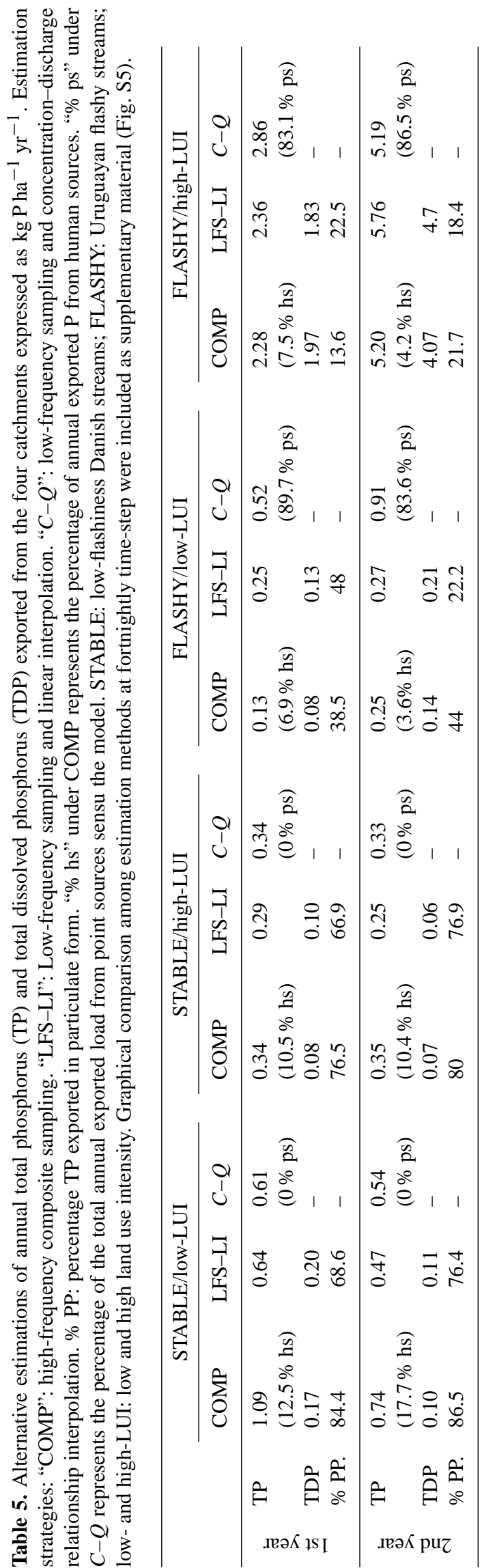

Hydrol. Earth Syst. Sci., 19, 4099-4111, 2015 
Table 6. The percentages summarizes the relative fit of alternative estimation methods in relation to the reference annually exported load

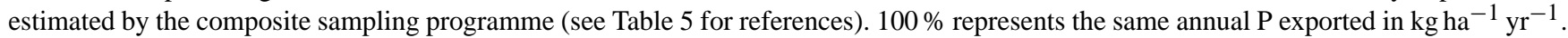
Values below $100 \%$ (italics) represent underestimation (less than 90\%) relative to the estimation of composite sampling. Values over $110 \%$ (bold) represent overestimation relative to the estimation of composite sampling. STABLE: low-flashiness Danish streams; FLASHY: Uruguayan flashy streams; low- and high-LUI: low and high land use intensity.

\begin{tabular}{|c|c|c|c|c|c|c|c|c|c|}
\hline & & \multicolumn{2}{|c|}{$\begin{array}{l}\text { STABLE } \\
\text { low-LUI }\end{array}$} & \multicolumn{2}{|c|}{$\begin{array}{l}\text { STABLE } \\
\text { high-LUI }\end{array}$} & \multicolumn{2}{|c|}{$\begin{array}{l}\text { FLASHY } \\
\text { low-LUI }\end{array}$} & \multicolumn{2}{|c|}{$\begin{array}{l}\text { FLASHY } \\
\text { high-LUI }\end{array}$} \\
\hline & & LFS-LI & $C-Q$ & LFS-LI & $C-Q$ & LFS-LI & $C-Q$ & LFS-LI & $C-Q$ \\
\hline \multirow{2}{*}{ 1st year } & $\mathrm{TP}$ & $58.7 \%$ & $56.0 \%$ & $85.3 \%$ & $100.0 \%$ & $192.3 \%$ & $400.0 \%$ & $103.5 \%$ & $125.4 \%$ \\
\hline & TDP & $117.6 \%$ & - & $125.0 \%$ & - & $162.5 \%$ & - & $92.9 \%$ & - \\
\hline \multirow{2}{*}{ 2nd year } & $\mathrm{TP}$ & $63.5 \%$ & $73.0 \%$ & $71.4 \%$ & $94.3 \%$ & $108.0 \%$ & $364.0 \%$ & $110.8 \%$ & $99.8 \%$ \\
\hline & TDP & $110.0 \%$ & - & $85.7 \%$ & - & $150.0 \%$ & - & $115.5 \%$ & - \\
\hline
\end{tabular}

gion (Table 6). The largest and disproportionate deviations of exported TP were obtained when applying the $C-Q$ model to the FLASHY/low-LUI catchment compared to the highfrequency composite sampling estimates (364-400\%; Table 6).

The contribution of PP to exported P was never lower than $65 \%$ of the annual exported TP in the STABLE catchments (Table 5). A contrasting pattern was recorded for FLASHY streams where the contribution of PP never exceeded $48 \%$ of TP, reaching values as low as $13.6 \%$ (Table 5). This pattern of a major contribution of PP in the STABLE catchments repeats itself in the estimations made with the lowfrequency instantaneous-grab samples, high-frequency composite samples, and flow-weighted concentrations (Fig. 5). We found a tendency to a higher, though rarely significant, dissolved P contribution in streams draining high-LUI catchments (Fig. 5).

The estimated contributions of TP from point sources and diffuse sources indicated that most of the TP export from the STABLE catchments came from diffuse sources as point source contribution from human sources only reached a maximum of $18 \%$ of the exported P (Table 5), but it was still too low to be detectable in our established $C-Q$ relationships as point sources (Table 4). Contrarily, in the FLASHY catchments point sources dominated the $\mathrm{P}$ export, always constituting more than $83 \%$ of the exported $\mathrm{P}$, with human sources contributing $<8 \%$, dairy cattle being the most probable source of the remaining $\mathrm{P}$ (Table 5).

\section{Discussion}

Our results show that climatic and hydrological variability affects the temporal dynamics of $\mathrm{P}$ in streams and that lowfrequency monitoring strategies may fail to adequately capture such dynamics.

As expected, we found strong concordance between climatic characteristics and stream hydrological regimes. Danish catchments have a lower rainfall that is more evenly dis- tributed during the year, with rare or no extreme rainfall events $\left(>50 \mathrm{~mm} \mathrm{day}^{-1}\right)$ and lower temperature (and therefore low evapotranspiration). These conditions resulted in streamflows characterized by higher stability (lower flashiness, $\mathrm{R}-\mathrm{B}$ index $=0.1-0.3$ in our study). In contrast, the Uruguayan streams exhibited a much higher contribution of stormflow to total flow and higher flashiness (R-B index $=0.9-1.3$ ), reflecting the local climate and likely also soil conditions. As a reference, reported data in the literature include daily maximum values of the $\mathrm{R}-\mathrm{B}$ index reaching 0.43 in mountain streams in Slovakia and Austria (Holko et al., 2011), 0.65 in 30 agriculturally dominated catchments in seven Nordic and Baltic countries (Deelstra et al., 2014), 1.01 at 204 stations in Michigan temperate streams (USA) (Fongers, 2012), and 1.32 at 515 stations in catchments located in six US Midwestern States (Baker et al., 2004).

The calculated annual TP export values in all streams fell within the range reported in the literature for comparable micro-catchments, for instance streams with grassland-agriculture production in Ireland $(0.89$ to $3.98 \mathrm{~kg} \mathrm{Pha}^{-1} \mathrm{yr}^{-1}$; Campbell et al., 2015), Irish streams with catchment farming activities $(0.12$ to 0.83 $\mathrm{kg} \mathrm{Pha}^{-1} \mathrm{yr}^{-1}$; Melland et al., 2012), and Norwegian streams ( 0.5 to $5.8 \mathrm{~kg} \mathrm{Pha}^{-1} \mathrm{yr}^{-1}$; Kronvang et al., 2005a). The temporal variability of exported PP followed the hydrological variability in the streams (Fig. 2), but the amount of exported P and PP (the latter likely derived from diffuse sources) did not systematically increase with increasing variability. This was valid for both Uruguayan catchments where the highest and lowest P loads were exported, and dissolved $\mathrm{P}$ forms always predominated over particulate forms. The pattern of $\mathrm{P}$ loads exported in relation to conditions of high hydrological variability was thus contrary to our a priori expectations (i.e., higher total and particulate $\mathrm{P}$ export from diffuse sources in connection with higher flashiness) (Table 5), likely due to other factors related to land use, less input of $\mathrm{P}$ with eroded stream bank material due to potential low content of $\mathrm{P}$ and maybe also less erosion (Kronvang 
et al., 2012) and particularly the presence/absence of point sources in the catchments.

Several factors may contribute to the predominance of dissolved $\mathrm{P}$ forms in the Uruguayan streams. The direct access of cattle to the stream channels is one of those reasons, being a practice that results in direct manure deposition in the water and trampling, and mobilization from stream bed sediments (James et al., 2007; Jarvie et al., 2010; Kronvang et al., 2012; Laubel et al., 2003; Sheffield et al., 1997; Trimble and Mendel, 1995). In the FLASHY/high-LUI catchment this contribution was exacerbated and further aggravated by the additional effects of the lack of slurry treatment in dairy facilities and the widespread no-till practices associated with the application of fertilizers over the soil surface (Sharpley and Smith, 1994; Sharpley et al., 1996). Some or all of these factors together may explain the high levels of TP, TDP, SRP, and SNRP, exceeding the maximum range found in 35 comparable Nordic/Baltic micro-catchments studied by Kronvang et al. (2007).

The contribution of TP from point sources was negligible in both STABLE catchment, but was always higher than $83 \%$ in the two FLASHY catchments irrespective of land use intensity. The magnitude of $\mathrm{P}$ point sources seems to have a much stronger influence on the hydrochemistry of the Uruguayan stream waters than do hydrological variability and flashiness per se. In contrast, the Danish pattern seems to be consistent with the well-documented reduced influence of $\mathrm{P}$ from point sources in northern Europe (European Environment Agency, 2005; Kronvang et al., 2005b). Apart from the climatic and hydrological differences between the analyzed catchments, the extremely high TP concentrations (as high as $4436 \mu \mathrm{g} \mathrm{P} \mathrm{L}^{-1}$ ), $\mathrm{P}$ exports (as high as $5.20 \mathrm{~kg} \mathrm{Pha}^{-1} \mathrm{yr}^{-1}$ ), and the extremely high proportion of dissolved $\mathrm{P}$ (as high as $86.4 \%$ ) estimated for the FLASHY/high-LUI catchment may have implications for the environmental regulations of farming production in Uruguay given the severe deterioration of water quality in our case study. Our results also provide insight into the future behavior of $\mathrm{P}$ in northern European temperate streams seen in the context of the predicted change in climate towards more extreme, warmer, and wetter conditions, probably giving flashier streams (Hanssen-Bauer et al., 2005).

The importance of understanding hydrology-driven variations in nutrient discharge will most likely increase in the near future. In our study, the performance of the different monitoring frequencies and $\mathrm{P}$ export estimation methods reflected the hydrological character or flashiness of the investigated streams. The performance of the low-frequency sampling programs in estimating TP and TDP exports was low in comparison with the high-frequency sampling program. Although the performance of the models evaluated with the Nash-Sutcliffe efficiency coefficient was generally low, the $C-Q$ method did not have a comparatively poor performance.
Although our study was limited to four representative catchments (for logistic reasons), our results suggest that a clear interaction between climate/hydrology and land use intensity occurred. This was shown by a lower deviation in the exported $\mathrm{P}$ estimations of the low-frequency sampling for the high-LUI than for the low-LUI catchments. However, the low-frequency sampling and linear interpolation method performed equally poorly for the FLASHY and STABLE streams. Our results suggest that climate and hydrological conditions may promote/may yield a bias in $\mathrm{P}$ load estimations at low sampling frequency, with a tendency towards underestimation for the hydrologically STABLE streams and overestimation for the FLASHY streams (Table 6). These results are in accordance with the findings of Richards and Holloway (1987) that the loads of P from diffuse sources (whose water concentration increases with runoff) tend to be underestimated, while the loads of $\mathrm{P}$ from point sources (whose concentration decreases with runoff) tend to be overestimated. This underlines the potentially high inadequacy of low-frequency sampling programs to properly depict stream dynamics, which is consistent with previous findings (e.g., Jones et al., 2012).

Research into P dynamics in subtropical FLASHY streams is in its initial phase. The expected intensification of agricultural production in many regions of the world, such as in southern South America, highlights the need for appropriate stream monitoring programs. Accurate estimation of P temporal dynamics and exports can help explain the linkages between climate, hydrology, land use, and water quality. Based on our findings, we suggest that the evaluation and use of more accurate monitoring methods, such as automatized flow-proportional water samplers and automatized bankside analyzers, should be prioritized whenever it is logistically possible. However, it seems particularly relevant in currently FLASHY systems and also in systems where climate change predictions suggest an increase in stream flashiness.

\section{The Supplement related to this article is available online at doi:10.5194/hess-19-4099-2015-supplement.}

Acknowledgements. We thank the technicians of AU in Silkeborg for their work in the field and lab. We acknowledge Carsten Brian Nielsen for technical assistance in the setup of monitoring stations in Uruguay. We are grateful for the field assistance from colleagues and students, the logistic support of Daniella Agrati and family, and landowners (Mendiverri \& Laturre) in Uruguay. We are grateful to Anne Mette Poulsen for manuscript editing.

G. Goyenola, F. Teixeira-de Mello, M. Meerhoff, I. GonzálezBergonzoni and N. Mazzeo received support from the SNI (Agencia Nacional de Investigación e Innovación, ANII, Uruguay). G. Goyenola was supported by a PhD scholarship from PEDECIBA. The study was funded by the Danish Council for Independent Research, a grant by ANII-FCE (2009-2749) Uruguay, and the National L'Oreal-UNESCO award for Women in ScienceUruguay with support of DICyT granted to M. Meerhoff. 
We also wish to thank the generous remarks by the reviewers and editor that helped us improve this paper.

Edited by: F. van Geer

\section{References}

Allaby, M.: Grasslands, Biomes of the Earth, Chelsea House, New York, 270 pp., 2006.

Arnold, J. G., Allen, P. M., Muttiah, R., and Bernhardt, G.: Automated base flow separation and recession analysis techniques, Ground Water, 33, 1010-1018, doi:10.1111/j.17456584.1995.tb00046.x, 1995.

Baker, D. B., Richards, R. P., Loftus, T. T., and Kramer, J. W.: A new flashiness index: Characteristics and applications to midwestern rivers and streams, J. Am. Water Resour. As., 40, 503522, doi:10.1111/j.1752-1688.2004.tb01046.x, 2004.

Bormann, F. H. and Likens, G. E.: Nutrient cycling. Science, 155, 424-428, 1967.

Bowes, M. J., Smith, J. T., Jarvie, H. P., and Neal, C.: Modelling of phosphorus inputs to rivers from diffuse and point sources, Sci. Total Environ., 395, 125-138, doi:10.1016/j.scitotenv.2008.01.054, 2008.

Campbell, J. M., Jordan, P., and Arnscheidt, J.: Using highresolution phosphorus data to investigate mitigation measures in headwater river catchments. Hydrol. Earth Syst. Sci., 19, 453464, doi:10.5194/hessd-11-10965-2014, 2015.

Carpenter, S. R., Caraco, N. F., Correll, D. L., Howarth, R. W., Sharpley, A. N., and Smith, V. H.: Nonpoint pollution of surface waters with phosphorus and nitrogen, Ecol. Appl., 8, 559-568, doi:10.1890/1051-0761(1998)008[0559:NPOSWW]2.0.CO;2, 1998.

Cassidy, R. and Jordan, P.: Limitations of instantaneous water quality sampling in surface-water catchments: Comparison with nearcontinuous phosphorus time-series data, J. Hydrol., 405, 182 193, doi:10.1016/j.jhydrol.2011.05.020, 2011.

Castaño, J. P., Giménez, A., Ceroni, M., Furest, J., and Aunchayna, R.: Caracterización agroclimática del Uruguay 19802009, INIA, Montevideo, 1-34, 2011.

Cordell, D., Drangert, J. O., and White, S.: The story of phosphorus: Global food security and food for thought, Global Environ. Change, 19, 292-305, 2009.

Deelstra, J., Iital, A., Povilaitis, A., Kyllmar, K., Greipsland, I., Blicher-Mathiesen, G., Jansons, V., Koskiaho, J., and Lagzdins, A.: Hydrological pathways and nitrogen runoff in agricultural dominated catchments in Nordic and Baltic countries, Agr. Ecosyst. Environ., 195, 211-219, doi:10.1016/j.agee.2014.06.007, 2014.

Defew, L. H., May, L., and Heal, K. V.: Uncertainties in estimated phosphorus loads as a function of different sampling frequencies and common calculation methods, Mar. Freshwater Res., 64, 373-386, doi:10.1071/MF12097, 2013.

Derpsch, R., Friedrich, T., Kassam, A., and Hongwen, L.: Current status of adoption of no-till farming in the world and some of its main benefits, Int. J. Agr. Biol. Eng., 3, 1-25, 2010

DMI: Precipitation and sun in Denmark, Danish Meteorological Institute, Copenhagen, 2015.
Dunn, O. J.: Multiple comparisons using rank sums, Technometrics, 6, 241-252, 1964.

Elser, J. and Bennett, E.: Phosphorus cycle: A broken biogeochemical cycle, Nature, 478, 29-31, 2011.

European Commission and European Soil Bureau Network: The European Soil Database distribution version 2.0, Tech. rep., European commission, http://eusoils.jrc.ec.europa.eu/ESDB_ Archive/ESDB_Data_Distribution/ESDB_data.html (last access: 14 November 2011), 2004.

European Environment Agency: Source apportionment of nitrogen and phosphorus inputs into the aquatic environment, European Environment Agency, Copenhagen, Denmark, 1-48, 2005.

Fongers, D.: Application of the Richards-Baker Flashiness Index to gaged Michigan rivers and streams, Water Resources Division, Michigan Department of Environmental Quality, Lansing, 1-141, 2012.

Grant, R., Laubel, A., Kronvang, B., Andersen, H. E., Svendsen, L. M., and Fuglsang, A.: Loss of dissolved and particulate phosphorus from arable catchments by subsurface drainage, Water Res., 30, 2633-2642, doi:10.1016/S0043-1354(96)00164-9, 1996.

Hanssen-Bauer, I., Achberger, C., Benestad, R. E., Chen, D., and Førland, E. J.: Statistical downscaling of climate scenarios over Scandinavia, Clim. Res., 29, 255-268, 2005.

Haygarth, P. M., Heathwaite, A. L., Jarvis, S. C., and Harrod, T. R.: Hydrological factors for phosphorus transfer from agricultural soils, in: Advances in Agronomy, edited by: Donald, L. S. Academic Press, San Diego, CA, 153-178, 1999.

Holko, L., Parajka, J., Kostka, Z., Škoda, P., and Blöschl, G.: Flashiness of mountain streams in Slovakia and Austria. J. Hydrol., 405, 392-401, doi:10.1016/j.jhydrol.2011.05.038, 2011.

James, E., Kleinman, P., Veith, T., Stedman, R., and Sharpley, A.: Phosphorus contributions from pastured dairy cattle to streams of the Cannonsville Watershed, New York, J. Soil Water Conserv., 62, 40-47, 2007.

Jarvie, H. P., Withers, P. J. A., Bowes, M. J., Palmer-Felgate, E. J., Harper, D. M., Wasiak, K., Wasiak, P., Hodgkinson, R. A., Bates, A., Stoate, C., Neal, M., Wickham, H. D., Harman, S. A., and Armstrong, L. K.: Streamwater phosphorus and nitrogen across a gradient in rural-agricultural land use intensity, Agr. Ecosyst. Environ., 135, 238-252, doi:10.1016/j.agee.2009.10.002, 2010.

Jones, A. S., Horsburgh, J. S., Mesner, N. O., Ryel, R. J., and Stevens, D. K.: Influence of sampling frequency on estimation of annual total phosphorus and total suspended solids loads, J. Am. Water Resour. As., 48, 1258-1275, doi:10.1016/j.agwat.2009.01.011, 2012.

Jordan, P. and Cassidy, R.: Technical Note: Assessing a 24/7 solution for monitoring water quality loads in small river catchments, Hydrol. Earth Syst. Sci., 15, 3093-3100, doi:10.5194/hess-153093-2011, 2011.

Kronvang, B. and Bruhn, A. J.: Choice of sampling strategy and estimation method for calculating nitrogen and phosphorus transport in small lowland streams, Hydrol. Process., 10, 14831501, doi:10.1002/(SICI)1099-1085(199611)10:11<1483::AIDHYP386>3.0.CO;2-Y, 1996.

Kronvang, B., Bechmann, M., Lundekvam, H., Behrendt, H., Rubaek, G. H., Schoumans, O. F., Syversen, N., Andersen, H. E., and Hoffmann, C. C.: Phosphorus losses from agricultural areas in river basins: Effects and uncertainties of tar- 
geted mitigation measures, J. Environ. Qual., 34, 2129-2144, doi:10.2134/jeq2004.0439, 2005a.

Kronvang, B., Jeppesen, E., Conley, D. J., Søndergaard, M., Larsen, S. E., Ovesen, N. B., and Carstensen, J.: Nutrient pressures and ecological responses to nutrient loading reductions in Danish streams, lakes and coastal waters, J. Hydrol., 304, 274-288, 2005b.

Kronvang, B., Vagstad, N., Behrendt, H., Bøgestrand, J., and Larsen, S. E.: Phosphorus losses at the catchment scale within Europe: an overview, Soil Use Manage., 23, 104-116, doi:10.1111/j.1475-2743.2007.00113.x, 2007.

Kronvang, B., Audet, J., Baattrup-Pedersen, A., Jensen, H. S., and Larsen, S. E.: Phosphorus Load to Surface Water from Bank Erosion in a Danish Lowland River Basin, J. Environ. Qual., 41, 304-313, doi:10.2134/jeq2010.0434, 2012.

Laubel, A., Kronvang, B., Hald, A. B., and Jensen, C.: Hydromorphological and biological factors influencing sediment and phosphorus loss via bank erosion in small lowland rural streams in Denmark, Hydrol. Process., 17, 3443-3463, doi:10.1002/hyp.1302, 2003.

Melland, A. R., Mellander, P. E., Murphy, P. N. C., Wall, D. P., Mechan, S., Shine, O., Shortle, G., and Jordan, P.: Stream water quality in intensive cereal cropping catchments with regulated nutrient management, Environ. Sci. Policy, 24, 58-70, doi:10.1016/j.envsci.2012.06.006, 2012.

Meyer, J. L. and Likens, G. E.: Transport and transformation of phosphorus in a forest stream ecosystem, Ecology, 60, 1255$1269,1979$.

Moriasi, D. N., Arnold, J. G., Van Liew, M. W., Bingner, R. L., Harmel, R. D., and Veith, T. L.: Model evaluation guidelines for systematic quantification of accuracy in watershed simulations, T. ASABE, 50, 885-900, 2007.

National Institute of Statistics: $8^{\circ}$ Censo nacional de población 2011, http://www.ine.gub.uy/censos2011/resultadosfinales/ florida.html (last access: 1 January 2015). 2011.

Richards, R. P. and Holloway, J.: Monte Carlo studies of sampling strategies for estimating tributary loads, Water Resour. Res., 23, 1939-1948, doi:10.1029/WR023i010p01939, 1987.
Sharpley, A. N. and Smith, S. J.: Wheat tillage and water quality in the Southern plains, Soil Till. Res., 30, 33-48, doi:10.1016/01671987(94)90149-X, 1994.

Sharpley, A. N., Daniel, T. C., Sims, J. T., and Pote, D. H.: Determining environmentally sound soil phosphorus levels, J. Soil Water Conserv., 51, 160-166, 1996.

Sheffield, R. E., Mostaghimi, S., Vaughan, D., Collins Jr., E., and Allen, V.: Off-stream water sources for grazing cattle as a stream bank stabilization and water quality BMP, T. ASABE, 40, 595604, 1997.

Stelzer, R. S. and Likens, G. E.: Effects of sampling frequency on estimates of dissolved silica export by streams: The role of hydrological variability and concentration-discharge relationships, Water Resour. Res., 42, 1-10, 2006.

Trimble, S. W. and Mendel, A. C.: The cow as a geomorphic agent - A critical review, Geomorphology, 13, 233-253, doi:10.1016/0169-555X(95)00028-4, 1995.

Valderrama, J. C.: The simultaneous analysis of total nitrogen and total phosphorus in natural waters, Mar. Chem., 10, 109-122, 1981.

Vinnerås, B.: Possibilities for sustainable nutrient recycling by faecal separation combined with urine diversion, $\mathrm{PhD}$, Acta Universitatis Agriculturae Sueciae, Agraria 353, Swedish University of Agricultural Sciences, Uppsala, 2002.

Wiberg-Larsen, P., Windolf, J., Bøgestrand, J., Baattrup-Pedersen, A., Kristensen, E. A., Larsen, S. E., Thodsen, H., Ovesen, N. B., Bjerring, R., Kronvang, B., and Kjeldgaard, A.: Vandløb 2012, NOVANA, Aarhus Universitet, DCE - Nationalt Center for Miljø og Energi, 84 s. - Videnskabelig rapport fra DCE - Nationalt Center for Miljø og Energi nr. 75, http://dce2.au.dk/pub/SR75. pdf (last access: 1 August 2015), 2013.

Wu, J. Y., Thompson, J. R., Kolka, R. K., Franz, K. J., and Stewart, T. W.: Using the Storm Water Management Model to predict urban headwater stream hydrological response to climate and land cover change, Hydrol. Earth Syst. Sci., 17, 4743-4758, doi:10.5194/hess-17-4743-2013, 2013.

Zar, J. H.: Biostatistical Analysis, 5th Edn., Prentice-Hall, Upper Saddle River, NJ, 2010. 